[McKenzie, D. (1995). The Irony of Educational Review. New Zealand Annual Review of Education, 4, 247-259]

\section{The Irony of Educational Review}

\section{DAVID MCKENZIE}

Abstract:

It is argued that the increasing criticisms of the Education Review Office which have been voiced in 1994 owe their origin to the failure of the Picot Committee to grasp that a distanced review authority which is required to act judgmentally will be unable to facilitate the co-operative activity that the process of educational review requires. It is proposed that the ERO structure be altered to encourage the incorporation of peer-review in the process.

A ssessing educational performance is a process which is shaped very much by the priorities of those who do the assessing and by the extent to which they are part of or a part from an institution which is being assessed. It is difficult to see in principle how the review process could be omitted from any professionally based teaching review activity, but history and current practice remind us that educational reviews conducted by external authorities who possess the power to influence the careers of teachers, can be miseducative in their outcome.

Typically, those who speak in the name of the government of the day assume that reviews on a regular basis of tax-funded schooling services will safeguard the quality of those services by keeping teachers "up-to-the-mark" through a process which identifies in a public way the day-to-day strengths and weaknesses that exist in given educational institutions. Commercially-based critics tend to argue further that such reviews are especially necessary in public schooling because compulsory school attendance requirements mean frequently that those who work in public schools are not subjected to the discipline of consumer market choice. But the great irony is that the more distant those who assess are from the school and the classroom, the more likely it will be that their publicised reviews will be based upon "objective" data that bear but a passing resemblance to the day-to-day educational reality that exists in schools. The more likely it will be also that teachers' energies will become concentrated upon manufacturing evidence designed to lead to an acceptable review report in lieu of seriously engaging themselves in the process of programme evaluation which educative development requires.
This is an irony that has been with us since the inception and expansion of state-financed systems of public schooling in the 19th century and it is by no means convincingly apparent that it is an irony which has disappeared following the post-Picot administrative reforms in New Zealand education. Accountability procedures established by the British government as it founded its first public schooling system provided the model for New Zealand to follow when it established a national system of primary schooling in 1877 . The British hit upon what seemed to them to be the ingenious idea of adjusting the payment of teachers according to the percentage of children in their classes who passed an annual examination set by a visiting school inspector on tasks specified in a national syllabus. This system of assessment which was appropriately called "payment-by-results", was not followed entirely by New Zealand's administrators who were aware that the State had more direct control over teacher recruitment and appointment than was the case in Britain. In this country, teachers' salaries were not determined directly by the outcome of external review but in all other respects the ingredients for producing a miseducative external review process in the name of accountability were present from the inception of national schooling in New Zealand. These included:

- a national task syllabus for each specified school subject divided into standards. These prescriptions (i.e., prescribed learning outcomes) were designed sequentially and authorised by an official who had no contact with the school, with school inspectors, with teachers or with parents. Thus the syllabus was "independent" or, in the jargon of current treasury speak, free from "provider-capture";

- the claim that the "prescribed tasks" in the syllabus were but minimum tasks and the assumption that good teachers would move beyond them and advance to more stimulating local teaching programmes of their own;

- clear specification of syllabus tasks. Since results in tests of prescribed syllabus tasks were held to constitute a proper comparative review of how well all public primary schools in New Zealand were progressing or failing, the prescriptions had to be designed to leave no misunderstanding of task content either by those administering the tests (the school inspectors) or those preparing students for the tests (teachers). Thus, for example, the prescription for standard one introduced by the Order-in-Council 24 September 1878 , for all public schools in New Zealand, read in part: 
Reading: Sentences composed of words of one syllable, and common words of two syllables to be read intelligently

Spelling: Easy words of one syllable

Writing: The small letters and the ten figures on slate, at dictation

Arithmetic: Counting, and oral addition by twos, threes, fours, and fives up to 100; numeration and notation to 999; addition sums of not more than three columns; multiplication of numbers not exceeding 999 by 2, 3, 4 and 5. (NZ Education Department, 1881:3)

- the doctrine of no responsibility. School Inspectors who conducted the review process via tests on the syllabus refused to be swayed by any complaints about the suitability or the quantum of syllabus tasks set by regulation. From their annual reports it was perfectly obvious that most inspectors did have serious misgivings about many of the assessment requirements but invariably they took the legalistic view that their statutory task was simply to report via "objective" test results whether schools were "efficient" or "inefficient". The "results" were produced in the form of the percentage of each class who passed a prescribed standard in the inspector's annual examination visit where each child in the standard classes was examined individually. The government was anxious that the public clearly understood the meaning of these "results". It decreed:

the school with the lowest average age and the highest percentage of passes in the same standards is the most efficient

... a high average age and a low percentage of passes indicates a school of the opposite character (AJHR, 1880:41).

To reinforce the point, the individual school examination results were published in the local newspaper in a percentage pass tabulation along with comparative results from the previous year;

- the review becomes the school. In the light of the above definition of school "efficiency", it was hardly surprising that teachers concentrated their energies on achieving good percentage pass results via a good class performance on examination day. Thus prescribed syllabus tasks intended by their author to be the minima quickly became the maxima. There was no time to waste on learning that would not be used on examination day and no means by which to advance into new territory beyond the syllabus prescribed in 1878 .
The major characteristic of early school review in New Zealand was thus its conservative character.

Within thirty years it was becoming increasingly accepted that this form of educational review needed to be modified because, as things stood, competitive consumer expectations raised by examination results curbed the initiative of the better teachers, encouraged poor "teaching to tests" by less gifted practitioners, and tempted some harassed souls to engage in outright dishonesty. One well-known ploy of last resort was to bribe retarded pupils to absent themselves on examination day - a most useful action from the point of view of an anxious teacher because the names of pupils who were marked "absent" were not entered into the all-important calculation of the percentage-pass result. Another common practice, employed especially by the head teachers of larger schools, was to delay admission to the class preparing for standard one to all pupils who seemed on their infant school record to be likely to become either incurably poor scholars or poor attenders or both. Since under the 1878 syllabus regulations, pupils in the primer classes were not required to be individually examined by the inspector, the infant classes provided a safe haven for those pupils whose poor performance might otherwise have marred an impressive percentage-pass result. More generally it was true that all other educational requirements were subordinated to the important day in the school year when the inspector came to examine the progress of each child in the standard classes. Extensive extra homework and examination coaching typically preceded this event, corporal punishment was frequently resorted to as an instrument of motivation, and often all children were kept at school for an extra hour per day for months prior to the examination.

By 1900, therefore, it was not difficult to make the case that the process of educational review, as it had first been designed in New Zealand schools, had become seriously miseducative in its general effect - a tool which reinforced conservatism rather than an instrument which promoted educational improvement. The irony which became increasingly apparent was that it was the review process itself which, in the name of quality assurance, contributed in large measure to encouraging poor teaching and learning. Public accounts of pupils who read their text aloud to the inspector while holding their books upside down or of pupils who gabbled off a geographic definition of an island on examination day but were unable to point to an island on a wall map when asked to do so by the inspector, would have been derisory had they not been so common in kind. In the end it was the mounting quantum of practical (not theoretical) evidence that persuaded parents, 
teachers, officials and finally the government that the review process established to meet the perceived requirements of accountability in 1877 needed to be radically altered.

The case for change was reinforced by the published arguments of overseas educationists (especially those from the United Kingdom) who were in the process of interrogating similar unsatisfactory outcomes of review processes in school systems with which they were familiar. Matthew Arnold, as well as having literary fame, and who was one of the earliest HMIs (Her Majesty's Inspectors), was the most noted 19th century critic of the belief that a given school's "efficiency" could be computed by summing a series of mechanistic "outputs". Initially, in his writings, Arnold concentrated his criticisms upon the "payment by results" system which was established in Britain in the 1860s and phased out 30 years later. But Arnold also came to see over time that the heart of the problem lay in the bureaucratic system of evaluation itself rather than in one particular policy. This was the argument that was developed further, and with much fanfare, by Edmond Holmes whose book What Is and What Might Be was published in 1911. Holmes wrote his seminal treatise after a working lifetime spent as a school inspector - a career in which he rose to the top position of Chief Inspector of Elementary Schools in England and Wales. He was hardly, therefore, a man whose writings could readily be dismissed as being those of an ignorant enthusiast or a crank.

In a somewhat extended "Mea Culpa", Holmes laid the blame for disappointing teaching and learning in the British schools squarely upon the ideological and social class distance between the teachers/parents/ pupils and school inspectors like himself:

For me [Holmes recalled], the children were so many examinees; and as they all belonged to the "lower orders", and as, according to the belief in which I had been allowed to grow up, the lower orders were congenitally inferior to the "upper classes", I took little or no interest in my examinees either as individuals or as human beings and never tried to explore their hidden depths (Holmes quoted in Bishop, 1971:144).

Apart from the class bias of the English schooling system which was wellknown, the important admission which Holmes makes here is that in spite of his having being a reviewer of educational progress it had never occurred to him that he had anything to learn from appraising how children went about their schooling tasks. Furthermore, their teachers fared no better in a system where the review process was nothing more than a crude form of governmental control. For this reason, Holmes concluded that teachers in the public elementary schools were the victims (not the authors) of a "vicious conception of education". He added:

For a third of a century "My Lords" required their inspectors to examine every child in every elementary school in England on a syllabus which was binding on all schools alike. In doing this they put a bit in the mouth of the teacher and drove him, at their pleasure, in this direction and that. And what they did to him they compelled him to do to the child (Holmes, 1911:7).

The sting in the tail of this conclusion is all-important. What Holmes is saying in effect is that in the absence of co-operation in the process of educational dialogue, the "review" becomes the daily agenda of the classroom with no means of advancing into new programmes and strategies.

It followed that all teachers desirous of receiving a good report would concentrate on what counted as measures of success and Holmes had no doubt as to how hollow (in educational terms) these could turn out be. As he turned the screw on the irony of the existing school review process, Holmes noted:

Timetables, schemes of work, syllabuses, record books, progress books, examination result books and the rest - hours and hours are spent by the teachers on the clerical work which these contrivances demand. And the hours so spent are too often wholly wasted. The worst of this machinery is that, so long as it works smoothly, all who are interested in the school are satisfied. But it may all work with perfect smoothness and yet achieve nothing that really counts (ibid:141).

The crux of this argument is that none of the above items is necessarily without value. They become so when presented as evidence of accomplishment to some external and essentially irresponsible authority (e.g., school inspector) or as evidence of compliance with some bureaucratic rule dictated from afar. A later progressive educationist, Caldwell Cook, declared:

The teacher may have a beautiful system ... throughly approved of by his majesty's inspector to boot. But what if the child's mind does not work orderly? (sic) - which happens to be the case. What will his majesty do then, poor thing? (Cook, 1917:3).

What New Zealand educationists learned from their initial experience therefore was than an externally-dictated review process which ventured to pass or fail pupils, teachers and schools according to specified bureaucratic criteria, stifled educational progress because neither the 
teachers nor the pupils nor, for that matter, parents or other interested adults had anything to contribute to the review process itself. They were persons who were acted upon. Worse still, if those who assessed others according to specified criteria (i.e., school inspectors) could legitimately claim that they bore no responsibility for those criteria, then schools were reduced to being reviewed on the basis of bureaucratic rules dreamed up far away from the realities of classroom life. Apart from the obvious miseducative effects which the review process produced in the classrooms - effects to which the writings of Holmes, Cook and others dramatically attested - the "closed" nature of the review process itself produced an horrendous example of what I have referred to elsewhere as the lack of educational progress which occurs when there is a statutory separation between those authorities responsible for curriculum prescription and those responsible for school evaluation or review (McKenzie, 1994:100)

After 1900, New Zealand abolished the separation of the powers of prescription and the powers of review, and much more discretion over the process of programme development and pupil evaluation was placed in the hands of individual teachers and schools. The change was gradua rather than radical and at certain points in the system (e.g., external examination in the final primary school year and the intermediate and senior years of post-primary school) all the criticisms associated with the earlier school review process came again to the fore. In retrospect it seems clear also that a major impediment to New Zealand teachers developing a more authoritative role in the educational review process lay in the contemporaneous development of teacher grading systems by means of which teachers' careers were determined by marks awarded by school inspectors who visited and assessed the classroom. These grading schemes, which lasted more than 70 years, were designed to protect and promote the professional development of teachers. But too often external judgments delivered in terms of grading marks kept teachers in the position of being "those who were reviewed" rather than encouraging them as professionals to participate in the review process itself. The common impression, which was not easily dispelled, was that "...the inspector's sting on the master's conscience" (Otago Daily Times, 1882) was the essence of what educational review was all about.

The golden years of educational progress in New Zealand seem to have been those associated with the late 1930s, the 1940s and the early 1950s. They were years identified with a government that was wholly committed to the quantitative and qualitative development of public education as a policy priority, with rising national wealth despite the trauma of war, and with a brilliant educational administrator in the person of C. E. Beeby, who served as Director of Education for much of this period. The clamour for accountability was still to be heard however; a clamour which was claimed to be the manifest reason for the establishment of the Currie Commission in 1958. It was a clamour that swelled as the economic fortunes of the nation waned in the 1970s and seriously collapsed in the mid 1980s. Many factors would seem to have contributed to the disappointed educational expectations which accompanied this decline. Despite the best endeavours of populist politicians, the economy could no longer deliver improved job opportunities for those who spent more years of their lives "in school" an outcome which led increasing numbers of observers and participants to question the widespread assumption in the Beeby years that more involvement in education would automatically return dividends to the individual and to the collective. As the revenue base declined, successive governments found the higher costs associated with providing a greater quantum of improved schooling services for all, increasingly difficult to sustain in the face of an eroding public faith in education as an unquestioned "good".

In New Zealand, as elsewhere, what returned to favour with the enthronement of "New Right" ideologies in political policy, was the nineteenth-century conviction that educational services, like all other services to individuals, should be subjected to the discipline of consumer choice. Thus educational services which were optimally efficient, it was held, would be those which responded competitively and successfully to what the market wanted. A further assumption (sometimes stated) was that the market mechanism would per se deliver to consumers the best services for the cheapest price if, and only if, the monopoly of providers was overturned. Thus in an ideal world of market competition there would be no need for any external review process. Weak schools which failed to satisfy their customers would go to the wall because they would have no custom. In short, the market process would become the review. However, State intervention in the shape of compulsory school attendance legislation which had been introduced for the benefit of the collective as well as the individual, meant that it was not possible for the market mechanism to act as neatly as illustrated above. Poor schools could stay in business because the law insisted that their services be used. To resolve this problem, the revived 19th century ideology associated with the "New Right" reached a compromise conclusion that where the state did intervene to compel a demand for educational services, services for which it was also a major provider, the interests of 
consumers (and ipso facto education efficiency) were best served by accounting those services on a regular basis and in terms of public and unambiguous criteria.

In this scenario, the school review process, which over the years had been moving to become one of educational process, returns to its 19th century origins of being external and judgmental in terms of quantitative criteria. The founder of the British system of "payment-by-results" had at that time summed the matter up succinctly when he declared "if the system is not cheap it will be efficient. If it is not efficient it will be cheap." A major point to note in the contemporary world is that according to the dogma of the "New Right" ideology it is entirely necessary that the review process be kept out of the hands of professional providers and that it therefore also be divorced from any genuine opportunity of being an educational process. This is because it is held that since monopolies of any kind are inherently impediments to the operation of a free market (although not, strangely enough, multinational corporations), educational progress in a market economy will result as long as those who provide educational services are unable to capture those services and so determine for their own comfort (or ideology) what services educational consumers would receive. Thus the review process, necessary because schools cannot be purely marketdriven, must be kept away from self-serving professionals. To this end the process must be public and provided by an "independent" authority which places "objective" reports on performance before consumers and those who employ professional practitioners.

It was in this context that the Education Review Office (ERO) was born as one of the major recommendations for institutional reform in New Zealand education contained in the Picot Report-Administering for Excellence (1988). The Picot committee, strongly influenced by the ideology emanating from the Treasury and the Business Roundtable, held it to be axiomatic that a satisfactory form of educational accountability, was impossible to be realised under the existing form of educational administration. As things stood, in the eyes of the Picot Committee, the Department of Education was its own initiator, jury and judge, a jury and judge moreover that was particularly prone to be captured by interested providers (e.g., teachers' associations) while at the same time stifling local initiative (e.g., language immersion schools). The thrust of Picot's recommendations, by way of contrast, was to place more policy initiatives and decisions in the hands of local school authorities; to encourage educational institutions, where possible, to compete for student enrolment; and to restrict the role of the central authority (now to be named the "Ministry") to performing clearly specified powers - e.g., allocation of finance per bureaucratic rule, prescribing national curricular requirements, approving written charters for all schools. With respect to the issue of accountability, the Picot Committee held it to be self-evident that the process must involve three elements:

- clear and specific aims and objectives, expressed as outcomes;

- control by the educational institution over the resources available to achieve the objectives; and

- monitoring by an outside agency of how well those objectives are met.

This was the genesis of what Picot called the Review and Audit Agency and which later came to be named the Education Review Office.

The words "neutral" and "independent" were defined in the context of the Picot Committee's thinking to mean free from provider bias. This was held to be all-important, while the concept of the review process having some educational benefit for providers was held either to be a contingent outcome or one not worth addressing under the heading of "accountability". Picot proposed that the Review and Audit Agency which would report directly to the Minister, would carry out regular institutional reviews, would also "comment on the performance of other elements of the administrative structure" (Picot, 1988:60) and would, further, conduct specific inquiries when requested to do so by the Minister. The authority of the review agency, as Picot made quite clear, was to lie in its "expertise" and its "distance" from the education system itself. Thus the Committee concluded:

Reviews should be undertaken at intervals of not more than two years. Those employed in this work should not have any other function. In particular they should not have any responsibility for advice and guidance to institutions, apart from any recommendations they wish to make in their reports (ibid:61).

In short, in order to free assessment and review from what were perceived to be the perils of "provider capture", the Picot Committee resurrected the doctrine of "expertise", "independence" and authoritative status, gained through freedom from educational responsibility, a doctrine which, as we have seen, has had a long and tatty history of producing miseducative outcomes. The heart of the paradox and the irony of the school review process is to be found here.

The point was further spelled out in Tomorrow's Schools, the document which in spite of stealing its title from one of the great works of twentieth-century progressive educational literature, was in fact no 
more than the Governments' decisions with respect to the Picot recommendations. It was now decided that:

An independent body - the Review and Audit Agency - will be established to ensure that institutions are accountable to the Government for the funds they spend and for meeting the objectives set out in their charter (Lange, 1988)

Thus it was inevitable that from the outset the new review agency would be perceived in accounting and judgmental terms from afar. Moreover its deliberate separation from other educational processes, despite the woeful history of such a strategy, ensured from the outset that the emphasis of all participants in the review process would come to be placed upon the production of reams of measurable/quantifiable data rather than upon a thoroughgoing participant analysis of present progress and consensus about the way forward.

For its part, the Picot Committee seemed to be wildly optimistic in the face of historical evidence to the contrary, that an independent review and audit process would also have an educative function of helping an institution to assess its own progress towards achieving its objectives. In their view, the whole review process could well become "a co-operative attempt to improve the quality of education being provided" (Picot, 1988:60) and one that was analogous to a business enterprise engaging "consultants to provide a wider more impartial and informed assessment of an institution's progress towards its objectives" (ibid).

The value of including persons beyond the institution is not to be disputed and the Picot Committee correctly concluded that a worthwhile process of educational review should indeed be a co-operative venture in which all parties are active participants in a quest, the outcome of which is not known in advance. The difficulty is that this is an argument which sits uneasily or not at all with the Committee's twin conviction that the process of accountability has to be one that entails no institutional responsibility on the part of those who review. It has therefore been a challenge for teachers to act co-operatively (as opposed to acting defensively) with persons empowered with an external agenda and an office which (correctly reported or otherwise) produced headlines in 1994 to the effect that more schools would be "failed" in future years.

The upsurge of complaints and doubts about the value of the ERO which has occurred in the past year would seem in retrospect to have stemmed primarily from the Picot Committee's failure to pursue the issue of educational assessment to the point of sound resolution. It chose instead to satisfy immediate dogmatic imperatives which were political in origin and in so doing it created a dubious legacy. There is no difficulty in accepting the case that the taxpayer is entitled to receive credible evidence that expenditure in public schools is both legitimate and prudent. The case for regular audit reviews on these grounds alone seems incontrovertible although even here there may be a case for interrogating the ideological baggage which seems to accompany flavour-of-the-month accounting systems. What has also to be accepted is that those who participate in the review process will inevitably do so with some tension and some anxiety because, if for no other reason, they are human beings who are reviewing progress or lack of same. Some of the complaints about the ERO procedures probably represent no more than this and as such, they would be likely to be heard no matter how the ERO process was conducted. What is a major difficulty for the ERO, as presently constituted, however, is the distanced judgmental role thrust upon it by the Picot Committee and Tomorrow's Schools, a role which arguably seriously hinders the review process from becoming a significant instrument of educational development.

Even from the point of view of those who assess, the present system is founded on shallow ground. The old saying goes that "distance lends enchantment" but the Picot Committee also saw the Review and Audit Agency as being a group which possessed genuine expertise. The fair question to ask therefore is how this expertise is to be maintained over a working career which involves "the expert" in being a peripatetic evaluator who never takes an educational initiative for anything? The strong likelihood is that any expertise initially possessed will decline the longer that the accredited expert has no admission to the educational initiative process and the longer that he/she is fed a diet of defensive "results". The point is not an idle one. The history of education is littered with examples of judgmental school inspectors who finished up talking to themselves because their habitual concentration upon bald "results" was gained at the expense of their losing their sensitivity to educational processes. The "results" do not speak for themselves. They require the empathetic interrogation of those whose "expertise" is up-to-date.

A much better approach would be to move the process of review to one which embraces peer review while maintaining the basic ERO administrative structure. In place of the existing permanent ERO staff, one could envisage a reviewing team which included a community representative, a financial expert, one permanent ERO member, and the remaining number composed of seconded professionals (for that one task) who possessed the relevant expertise. For example, differen seconded teams would be required when reviewing a pre-school 
institution or a Maori language school or a post-primary institution. What this policy change would do would not only save the Government money, it would also introduce the concept of peer review and so give life to the concept of an educational review based upon co-operation which the Picot Report flirted with briefly.

A basic premise of peer review is that experienced professionals can expect both to review and to be reviewed in a public manner - a process which can concentrate the mind and restrain fantasy in a most wonderful manner. Nor is this proposal one which is wildly radical. For many years the practice of specialist subject secondment for one or several school inspections was known in the post-primary inspectorate: And even the Picot Report raised the possibility of co-opting professionals in the review process. All that is needed in fact is that we throw off the political shibboleths which at present hinder us from moving the review process beyond irony and toward educational development and resolution.

\section{References}

\section{AJHR. 1880, Vol.2, H-I:41.}

Bishop, A. S. The Rise of Central Authority in English Education, London: CUP, 1971:144

Cook, C. The Play Way, London: Heinemann, 1917:3.

Holmes, E. What Is and What Must Be, London: Constable \& Co, 1911.

Lange, D. Tomorrow's Schools, The Reform of Education Administration in New Zealand, Wellington: Government Printer, 1988.

McKenzie, D. New Zealand Journal of Educational Studies, 29:1,1994:100.

New Zealand Education Department. The Standards, Wellington: Government Printer, 1881:3.

Otago Daily Times. 3 May 1882.

Picot, B. Administration for Excellence, Effective Administration in Education Wellington: Government Printer, 1988.

\section{The author}

David McKenzie taught for many years in the Education Department of the University of Otago where he was also Assistant Vice-Chancellor (Humanities). He has published extensively in the areas of history of education and New Zealand education. He is currently a Research Fellow in Education. 